\title{
DAMPAK EKONOMI PENGEMBANGAN COMMUNITY BASED TOURISM TERHADAP MASYARAKAT LOKAL DI KABUPATEN MALANG (Studi Kasus Destinasi Wisata Cafe Sawah Pujon Kidul)
}

\author{
Tomi Agfianto \\ Universitas Udayana \\ Email: tomi.agfiant@gmail.com \\ Made Antara \\ Universitas Udayana \\ Email: antara_unud@yahoo.com \\ I Wayan Suardana \\ Universitas Udayana \\ Email: suar.dana@gmail.com
}

\begin{abstract}
This study aims to identify and analyze the extent to which CBT can have an impact on the income of local people originating from tourist expenditure in tourist destinations. This study uses quantitative research methods from the results of questionnaires to tourists, labor, business units, and managers at Cafe Sawah tourist destinations in Pujon Kidul Village, Malang Regency. The finding in this study is that the multiplier effect value in the Cafe Sawah tourist destination has a Keynesian Income Multiplier number of 0.27 or 001.00 , so that the destination has not been able to have a significant impact on the surrounding community, especially those who do business in that location. The results of this study explain that Community Based Management has not been able to provide a significant impact, so there needs to be a fundamental evaluation of the local district government where the function of the government is as a regulation and providing assistance to existing tourism destinations in the area.
\end{abstract}

Keywords: Community Based Tourism, Sustainable Tourism, Tourism Economic Impact, Cafe Sawah 


\section{Pendahuluan}

Kurun lima tahun terakhir sektor pariwisata menjadi salah satu sektor unggulan yang menopang perekonomian negara Indonesia. Hal ini tidak terlepas dari apa yang dilaporkan oleh Kementerian Pariwisata (2016) yang menyebutkan pada tahun 2015 sektor pariwisata telah mampu menyumbangkan devisa sebesar Rp. 144 triliun dengan laju rata-rata pertumbuhan penerimaan devisa sebesar 13 persen. Nominal ini meningkat secara signifikan dan jauh lebih besar dari komoditas lain yang terlebih dulu dikenal sebagai komoditas penghasil devisa seperti migas, kelapa sawit, karet olahan, dan batu bara. Selain menyumbangkan devisa negara yang besar menurut data BPS (2014). Tidak bisa dipungkiri, tingginya sumbangan devisa negara, peningkatan pendapatan asli daerah, dan kemampuan dalam menyerap tenaga kerja menjadikan sektor pariwisata mendapat perhatian untuk terus dikembangkan sebagai sektor unggulan, sehingga terjadilah pemerataan pembangunan (Muljadi, 2012).

Pengembangan industri pariwisata yang berbasis pada sustainable oriented model sudah mulai banyak dikembangkan di Indonesia. Salah satu daerah yang sudah menjadikan sustainable oriented model sebagai dasar dalam mengembangkan kawasannya adalah Malang Raya Jawa Timur. Meskipun destinasi seperti Malang telah memberikan dampak ekonomi terhadap masyarakat lokal, menjadi menarik untuk diukur seberapa signifikan model pengembangan pariwisata tersebut memberikan dampak positif terhadap pendapatan masyarakat lokal. Menarik untuk diketahui apakah masyarakat mendapatkan dampak yang signifikan dari community based tourism dengan keadaan minimnya fasilitas dan aksesibilas tersebut. Berdasarkan Fenomena tersebut, artikel ini bertujuan untuk membahas mengenai (1) Karakteristik wisatawan di Cafe Sawah Pujon Kidul dan (2) Dampak ekonomi yang ditimbulkan oleh aktivitas pariwisata Cafe Sawah Pujon Kidul. 


\section{Landasan Teori dan Konsep}

\section{Pariwisata Berkelanjutan (Sustainable Tourism)}

Sunaryo (2013) menjelaskan pariwisata massal memunculkan keprihatinan dari berbagai aspek mengenai dampak negatif yaitu aspek sosial, budaya, dan ekonomi yang ditimbulkan oleh aktivitas tersebut, sehingga dirasa pariwisata berkelanjutan merupakan jawaban dari kritik - kritik yang timbul.

Konsep dasar pengembangan pariwisata berkelanjutan adalah menitik beratkan terhadap tiga pilar yaitu masyarakat lokal, lingkungan sekitar, dan ekonomi. Konsep dasar tersebut pada akhirnya berimplikasi terhadap keseimbangan antara pendapatan yang dirasakan oleh masyarakat, pemberdayaan, adat istiadat, nilai - nilai kearifan lokal serta kelestarian lingkungan sekitar kawasan wisata.

McIntyre (1993) dalam buku yang berjudul Sustainable Tourism Development Guide for Local Planner dinyatakan bahwa ada tiga komponen penting yang saling terkait dalam pengembangan pariwisata berkelanjutan dan apabila komponen ini dilibatkan akan terjadi peningkatan kualitas hidup. Ketiga komponen yang dimaksud adalah:

\section{1) Industri Pariwisata}

Industri pariwisata adalah dapat meningkatkan ekonomi berupa lapangan pekerjaan, meningkatkan pendapatan, mendorong penanaman modal, meningkatkan kesempatan untuk mengembangkan bisnis.

2) Lingkungan

Agar kepariwisataan dapat bertahan lama maka tipe dan tingkat aktivitas kepariwisataan harus seimbang antara kapasitas yang tersedia, baik sumber daya alam maupun buatan. 
3) Masyarakat

Peningkatan taraf hidup masyarakat adalah faktor pokok. Apabila mereka dilibatkan dalam berbagai hal maka mereka akan termotivasi dan merasa bertanggungjawab akan keputusan yang mereka ambil.

Pihak perencana atau planner harus mengikutsertakan masyarakat sejak awal pada tahap perencanaan. Penjelasan tersebut dapat digambarkan dalam Gambar 2.1:

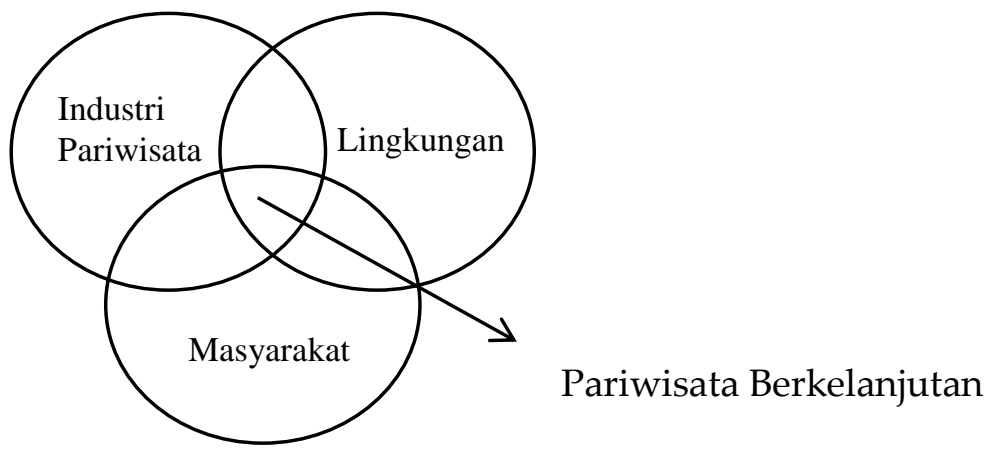

Gambar 1. Pariwisata Berkelanjutan WTO

Sumber : Gautama (2010)

\section{Dampak Ekonomi}

Pariwisata menjadi faktor penting dalam ekonomi dikarenakan pariwisata merupakan faktor pendorong suatu perkembangan beberapa sektor ekonomi. Dengan meningkatnya sektor pariwisata meningkat pula industri - industri terkait yang erat hubungannya dengan sektor pariwisata diantaranya handycrafts, souvenir goods serta sektor pertanian di mana wisatawan membutuhkan makanan untuk dikonsumsi.

Lebih lanjut, Menurut Marine Ecotourism for Atlatic Area (2001) dalam kaitannya dengan pendapatan masyarakat, terdapat tiga kelompok dampak ekonomi yang ada yaitu efek langsung (Direct Effectcs), efek tidak langsung (Indirect Effects), dan efek lanjutan / induksi (Induced Effects). Dalam penerapannya, efek tidak langsung dan efek induksi kadang - kadang disebut sebagai efek sekunder (Secondary Effects) yang mengikuti efek langsung sebagai efek primer (Primary Effect). 
Septianti (2013) juga menjelaskan bahwa dampak ekonomi langsung dapat dilihat dari transaksi antara pengunjung dengan unit usaha, apabila unit usaha berasal dari masyarakat lokal maka dampak ekonomi tersebut dapat dirasakan oleh masyarakat lokal. sektor-sektor yang mensuplai barang dan jasa kepada komponen usaha penerima awal/pertama pembelanjaan pengunjung. Menurut (Septianti, 2013) dampak ekonomi tidak langsung dapat dilihat dari pengeluaran unit usaha didalam kawasan destinasi serta pendapatan tenaga kerja yang bekerja pada unit usaha yang berada di destinasi tersebut. Ketika kegiatan usaha tersebut melibatkan masyarakat lokal dalam aktivitas usaha maka secara tidak langsung upah yang diterima oleh tenaga kerja tersebut menimbulkan dampak ekonomi lokasi tersebut.

Menurut lembaga Marine Ecotourism for Atlantic Area (META) dalam Anonim (2001) dampak ekonomi diukur dengan menggunakan efek penggandaan dari aliran uang yang yang terjadi. Dalam mengukur dampak ekonomi kegiatan pariwisata di tingkat lokal digunakan dua tipe penggandaan, yaitu: (1) Keynesian Local Income Multiplier yaitu nilai yang menunjukkan berapa besar pengeluaran wisatawan berdampak pada peningkatan pendapatan masyarakat lokal; (2) Ratio Income Multiplier yaitu nilai yang menunjukkan seberapa besar dampak langsung yang dirasakan dari pengeluaran wisatawan berdampak pada keseluruhan ekonomi lokal. Penggandaan ini mengukur dampak tidak langsung dan dampak lanjutan yang diterima.

Kriteria yang ada dalam penilaian angka Keynesian Local Income Multiplier, Ratio Income Multiplier Tipe I, Ratio Income Multiplier Tipe II adalah sebagai berikut:

1) Apabila nilai tersebut kurang dari atau sama dengan nol $(\leq 0)$, maka destinasi tersebut di dalam aktivitas wisatanya belum bisa memberikan dampak ekonomi khususnya terhadap pendapatan masyarakat.

2) Apabila nilai tersebut diantara angka nol dan satu $(0<x<1)$, maka destinasi tersebut di dalam aktivitas wisatanya masih memiliki nilai dampak ekonomi yang rendah khususnya terhadap pendapatan masyarakat; dan 
3) Apabila nilai-nilai tersebut lebih besar atau sama dengan satu $(\geq 1)$, maka destinasi tersebut di dalam aktivitas wisatanya telah mampu memberikan dampak ekonomi khususnya terhadap pendapatan masyarakat.

\section{Metode Penelitian}

Lokasi penelitian adalah di Desa Wisata Cafe Sawah Pujon Kidul Kabupaten Malang yang dilakukan pada Februari - April 2018. Populasi dalam penelitian ini adalah seluruh wisatawan yang telah melakukan wisata di Cafe Sawah dengan kriteria usia lebih dari atau sama dengan 17 tahun dan telah membelanjakan uangnya di Destinasi Cafe Sawah. Pertimbangan usia menjadi penting karena rata rata usia 17 tahun telah dapat membelanjakan keuangan pribadinya pada destinasi wisata tanpa adanya intervensi dari orang lain. Selain wisatawan, tenaga kerja dan pemilik unit usaha pada destinasi wisata menjadi populasi dalam penelitian ini untuk mengetahui pendapatan dan pengeluaran yang dilakukan. Sampel yang digunakan adalah 110 sampel dengan rincian 50 sampel wisatawan, 30 sampel unit usaha, dan 30 sampel tenaga kerja.

Untuk mengukur dampak ekonomi langsung, dampak ekonomi tidak langsung, dan dampak ekonomi lanjutan pada Cafe Sawah digunakan teori multiplier effect / efek penggandaan. Dalam mengukur dampak ekonomi kegiatan pariwisata di tingkat lokal, terdapat dua tipe pengganda, yaitu (Anonim, 2001):

(a) Keynesian Local Income Multiplier,

Keynesian Local Income Multiplier merupakan nilai yang menunjukkan berapa besar pengeluaran wisatawan berdampak pada peningkatan pendapatan masyarakat lokal.

(b) Ratio Income Multiplier,

Ratio Income Multiplier yaitu nilai yang menunjukkan seberapa besar dampak langsung yang dirasakan dari pengeluaran wisatawan berdampak pada 
keseluruhan ekonomi lokal. Pengganda ini mengukur dampak tidak langsung dan dampak induced.

Secara matematis dirumuskan:

Keynesian Income Multiplier $=\frac{\mathrm{D}+\mathrm{N}+\mathrm{U}}{\mathrm{E}}$

Ratio Income Multiplier, Tipe $\mathrm{I}=\frac{\mathrm{D}+\mathrm{N}}{\mathrm{D}}$......

Ratio Income Multiplier, Tipe II $=\frac{\mathrm{D}+\mathrm{N}+\mathrm{U}}{\mathrm{D}}$

Di mana:

E : pengeluaran wisatawan (Rupiah)

D : pendapatan masyarakat yang diperoleh secara langsung dari E.

$\mathrm{N}$ : pendapatan masyarakat yang diperoleh secara tidak langsung dari E

$\mathrm{U}$ : pendapatan masyarakat yang diperoleh secara induced dari E

\section{Hasil dan Pembahasan}

\section{Cafe sawah}

Cafe Sawah merupakan sebuah destinasi wisata unggulan Kabupaten Malang berbasis masyarakat lokal yang dikelola oleh sebuah organisasi desa "Pokdarwis (Kelompok Sadar Wisata) Capung Alas". Berdasarkan pemetaannya luas wilayah Cafe Sawah Desa Pujon Kidul adalah $8500 \mathrm{~m}^{2}$. Secara administratif Cafe Sawah terletak di Kabupaten Malang tepatnya di Desa Pujon Kidul, Kec. Pujon. Luas wilayah Desa Pujon Kidul sendiri kurang lebih 323.159 Hektar dengan jumlah KK yang menempati desa tersebut sebanyak 1.324 Kepala Keluarga. Selain pariwisata, sumber mata pencaharian masyarakat desa tersebut adalah bertani, berkebun, berternak dan juga berdagang mengingat kondisi geografis desa tersebut adalah persawahan. Cafe Sawah mulai berdiri sejak tahun 2010 dengan konsep awal adalah wisata edukasi kepada anak-anak sekolah baik dari jenjang TK sampai dengan SMA. Selain pemandangan menjadi daya tarik utama wisata edukasi, tanam sayur dan petik buah menjadi paket wisata yang ditawarkan pada destinasi Cafe Sawah waktu itu. Tetapi pada perkembangannya dirasa jumlah kunjungan wisatawannya kurang 
begitu signifikan. Selain karena segmen wisatawannya hanya terbatas kepada siswa sekolahan saja, sistem penerimaan wisatawannya pun harus melalui proses reservasi tempat dahulu agar dapat menikmati makanan dan minuman yang disajikan.

Selain pihak internal yang merupakan pihak pengelola destinasi wisata sebagai sebuah lembaga yang mempromosikan destinasi wisata Cafe Sawah, Pemerintah Kabupaten Malang melalui Bidang Pemasaran Wisata Dinas Pariwisata dan Kebudayaan memiliki program - program kerja untuk meningkatkan jumlah kunjungan wisatawan diberbagai lokasi wisata Kabupaten Malang salah satunya adalah destinasi wisata Cafe Sawah. Dengan adanya kelembagaan yang mempromosikan Kabupaten Malang diharapkan Cafe Sawah lebih dikenal oleh wisatawan dan hal ini dapat meningkatkan jumlah kunjungan wisatawan ke Kabupaten Malang khususnya Cafe Sawah.

\section{Karakteristik wisatawan}

Karakteristik responden wisatawan yang berkunjung ke Cafe Sawah Pujon Kidul dapat dilihat seperti pada Tabel 1 berikut. 
Dampak Ekonomi Pengembangan Community Based Tourism...

Tabel 1. Karakteristik Responden Wisatawan Cafe Sawah

\begin{tabular}{|c|c|c|c|}
\hline No. & Karakteristik & Frekuensi & Persentase (\%) \\
\hline \multirow[t]{6}{*}{1} & Usia (tahun) & & \\
\hline & $17-20$ & 16 & 32,00 \\
\hline & $21-30$ & 12 & 24,00 \\
\hline & $31-40$ & 15 & 30,00 \\
\hline & $\geq 40$ & 7 & 14,00 \\
\hline & Jumlah & 50 & 100,00 \\
\hline \multirow[t]{8}{*}{2} & Tingkat Pendidikan & & \\
\hline & SD & 2 & 4,00 \\
\hline & SMP & 1 & 2,00 \\
\hline & SMA & 15 & 30,00 \\
\hline & Diploma & 3 & 6,00 \\
\hline & S1 & 27 & 54,00 \\
\hline & S2 & 2 & 4,00 \\
\hline & Jumlah & 50 & 100,00 \\
\hline \multirow[t]{8}{*}{3} & Pekerjaan & & \\
\hline & Pelajar & 17 & 34,00 \\
\hline & PNS & 6 & 12,00 \\
\hline & Karyawan BUMN & 3 & 6,00 \\
\hline & Karyawan & 20 & 40,00 \\
\hline & Swasta/Wiraswasta & & \\
\hline & Ibu Rumah Tangga & 4 & 8,00 \\
\hline & Jumlah & 50 & 100,00 \\
\hline \multirow[t]{7}{*}{4} & Pendapatan & & \\
\hline & $\leq 500.000$ & 13 & 26,00 \\
\hline & $500.001-1.500 .000$ & 7 & 14,00 \\
\hline & $1.500 .001-2.500 .000$ & 7 & 14,00 \\
\hline & $2.500 .001-3.500 .000$ & 9 & 18,00 \\
\hline & $\geq 3.500 .001$ & 14 & 28,00 \\
\hline & Jumlah & 50 & 100,00 \\
\hline \multirow[t]{4}{*}{5} & Daerah Asal & & \\
\hline & Malang Raya & 20 & 40,00 \\
\hline & Luar Malang Raya & 30 & 60,00 \\
\hline & Jumlah & 50 & 100,00 \\
\hline \multirow[t]{5}{*}{6} & Jenis Kendaraan & & \\
\hline & Motor & 24 & 48,00 \\
\hline & Mobil & 26 & 52,00 \\
\hline & Kendaraan Umum & 0 & 0,00 \\
\hline & Jumlah & 50 & 100,00 \\
\hline
\end{tabular}

Sumber: Data diolah, 2018 
Berdasarkan tabel 1 dapat dilihat bahwa wisatawan yang berwisata di Cafe Sawah memiliki usia beriksar 17-20 tahun dan 31-40 tahun yaitu sebesar 32,00 persen dan 30,00 persen dari total responden. Hal tersebut sesuai dengan aktraksi wisata yang ditawarkan oleh Cafe Sawah yaitu cocok untuk anak muda yang gemar melakukan swafoto (selfie) karena terdapat berbagai titik foto yang bagus untuk diabadikan. Selain itu juga cocok untuk wisatawan yang mempunyai keluarga dan anak kecil karena umumnya atraksi wisata yang berada di Cafe Sawah berupa outbond dan permainan menaiki kuda dengan track atau jalur kecil yang telah ditentukan untuk anak - anak. Tingkat pendidikan responden dalam hal ini didominasi oleh wisatawan yang memiliki tingkat pendidikan terakhir Sarjana Strata 1 dengan total sebesar 54,00 persen dari total responden. Rata - rata wisatawan merupakan wisatawan dari luar Malang Raya dengan sebagian besar membawa kendaraan pribadi berupa mobil yaitu sebesar 52,00 persen.

\section{Pengeluaran wisatawan}

Perhitungan dampak ekonomi Cafe Sawah dapat dilihat dari perhitungan pengeluaran wisatawan di lokasi wisata. Persentasi dari pengeluaran diperoleh dari hasil penyebaran kuesioner dengan 50 responden wisatawan yang di lokasi yaitu Cafe Sawah. Data mengenai persentase pengeluaran pengunjung dapat dilihat seperti pada Tabel 2. 
Dampak Ekonomi Pengembangan Community Based Tourism...

Tabel 2. Proporsi Pengeluaran Pengunjung dan Kebocoran yang Terjadi di Destinasi Wisata Cafe Sawah

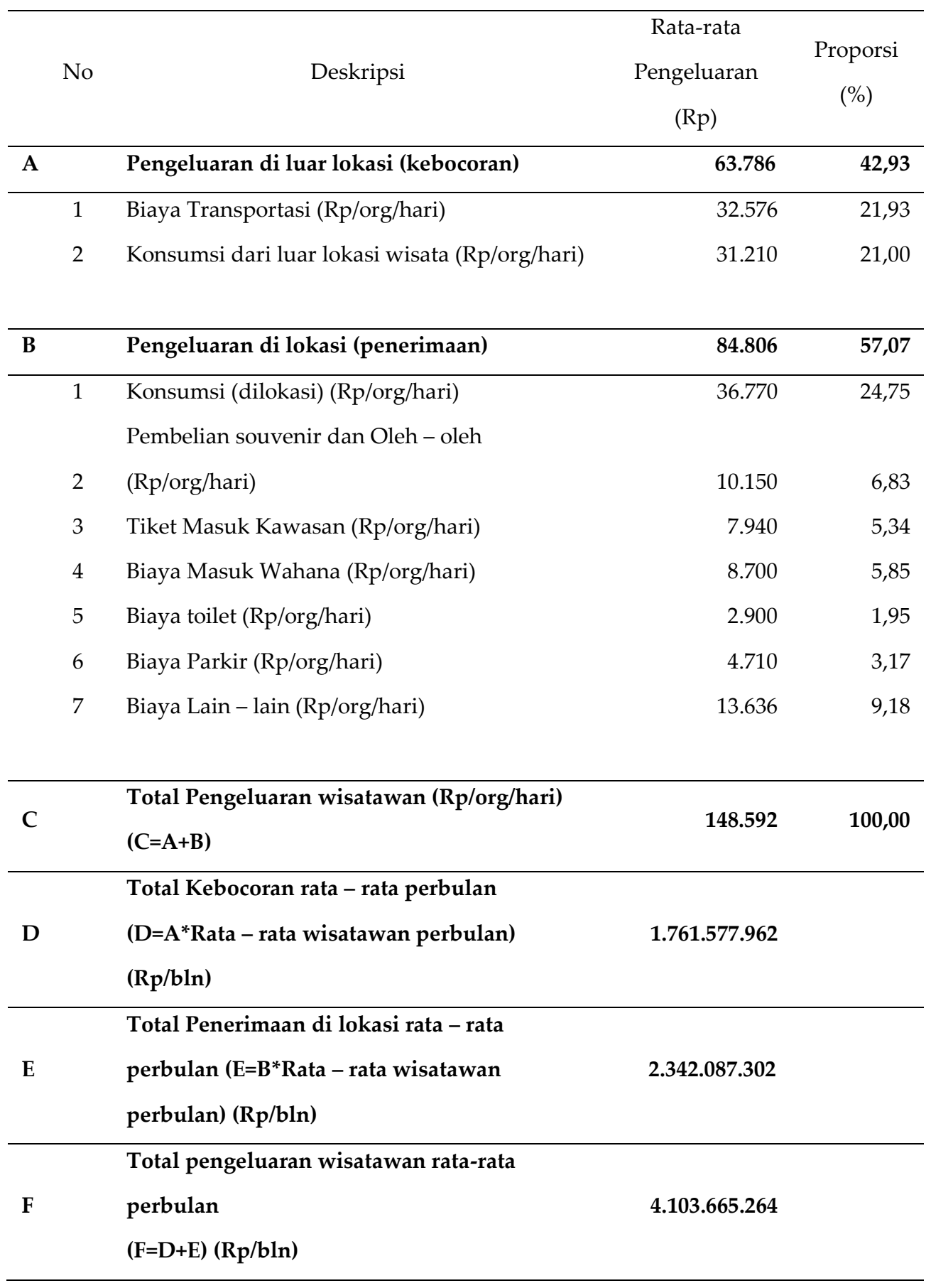

Sumber: Data diolah, 2018

Data sekunder diperoleh dari pengelola destinasi wisata, 2018

Catatan: Jumlah rata - rata kunjungan wisatawan perbulan (Nov 2016 - Okt 2017) adalah 27.617 wisatawan 
Berdasarkan Tabel 2 yang berasal dari hasil penyebaran kuesioner kepada wisatawan dan pengelola Cafe Sawah dapat diperoleh informasi bahwa proporsi transportasi yakni sebesar 21,93 persen dan biaya konsumsi yang dikeluarkan selama perjalanan tetapi belum sampai di lokasi wisata adalah sebesar 21,00 persen. Hal ini disebabkan oleh banyaknya pengunjung yang berasal dari luar kota Malang Raya, sehingga biaya transportasi yang dikeluarkan untuk pembelian bahan bakar sangat besar. Lebih lanjut akses menuju destinasi wisata pun tidak terdapat adanya public transportation sehingga setiap pengunjung yang ingin mengunjungi Cafe Sawah harus mengeluarkan biaya transportasi menggunakan kendaraan pribadi. Lebih lanjut wisatawan merupakan wisatawan yang berasal dari luar kota yang tentunya mengeluarkan biaya konsumsi sebelum tiba di lokasi wisata. Pengeluaran konsumsi diluar destinasi wisata sendiri sebesar 21,00 persen dari total tourist expenditure selama melakukan perjalanan wisata atau rata - rata sebesar $\operatorname{Rp} 31.210$,per wisatawan. Hal ini cukup signifikan kebocoran yang dilakukan oleh wisatawan mengingat proporsinya sendiri adalah 42,93 persen. Berdasarkan Tabel 5.2 dapat diketahui bahwa rata - rata per bulan pengunjung Cafe Sawah dari bulan november 2016 - oktober 2017 adalah sebesar 27.617 wisatawan. Ketika proporsi pengeluaran rata - rata perbulan wisatawan yang dilakukan di destinasi wisata adalah sebesar 57,07 persen maka total pengeluaran yang dilakukan di destinasi wisata adalah sebesar Rp 2.342.087.302,--

\section{Dampak ekonomi langsung}

Dampak ekonomi langsung merupakan dampak yang langsung diterima pada suatu destinasi wisata tersebut yang bersumber dari pengeluaran wisatawan pada saat melakukan aktivitas wisata. Dampak ekonomi langsung dapat dilihat dari pendapatan bersih pemilik unit usaha. Adapun perhitungan dampak langsung yang dirasakan oleh unit usaha dapat dilihat pada Tabel 3. 
Tabel 3. Dampak Ekonomi Langsung di Cafe Sawah

\begin{tabular}{lcccc}
\hline \multicolumn{1}{c}{ Jenis Usaha } & $\begin{array}{l}\text { Responden } \\
\text { Unit Usaha }\end{array}$ & $\begin{array}{c}\text { Jumlah } \\
\text { Unit } \\
\text { Usaha }\end{array}$ & $\begin{array}{c}\text { Rata - Rata } \\
\text { Pendapatan } \\
\text { Perbulan }\end{array}$ & $\begin{array}{c}\text { Dampak } \\
\text { Ekonomi } \\
\text { Langsung }\end{array}$ \\
\hline Kios Makanan dan Minuman & (a) & (b) & (c) & $\left(\mathrm{d}=\mathrm{b}^{*} \mathrm{c}\right)$ \\
Kios Oleh - oleh dan Souvenir & 17 & 48 & 2.355 .882 & 113.082 .353 \\
Permainan yang di kelola & 9 & 25 & 2.722 .222 & 68.055 .556 \\
masyarakat & 3 & 8 & & \\
Usaha Toilet & 1 & 4 & 300.000 & 1.200 .000 \\
\hline Total & 30 & 85 & 6.244 .771 & 191.671 .242 \\
\hline
\end{tabular}

Sumber: Data diolah, 2018

Setiap jenis usaha memiliki pendapatan yang berbeda - beda berdasarkan jenis usaha yang mereka jalankan. Berdasarkan Tabel 5.3 Secara individu Kios Oleh - oleh memiliki jumlah pendapatan paling besar yaitu rata - rata Rp. 2.722.222,- per unit usaha per bulan. Lebih lanjut, jika akumulasi dari kelompok unit usaha, kios makanan dan minuman memiliki jumlah pendapatan yang paling tinggi karena jumlah dari pemilik usaha yang berada di lokasi wisata Cafe Sawah mendominasi yaitu 48 unit usaha. Berdasarkan total jumlah pendapatan yang diterima oleh pemilik usaha kios makanan dan minuman, usaha ini paling tinggi dengan jumlah pendapatan rata - rata perbulan adalah Rp113.082.353,-, sedangkan rata - rata pendapatan bersih perbulan yang diterima oleh usaha penyediaan toilet di lokasi wisata memiliki jumlah pendapatan bersih paling rendah yaitu sebesar Rp 300.000,perbulan. Dengan jumlah pemilik usaha penyediaan toilet 4 unit usaha sehingga rata - rata jumlah pendapatan bersih perbulan yang pemilik usaha terima adalah sebesar Rp. 1.200.000,-. Total dampak langsung yang diterima oleh unit usaha di lokasi wisata Cafe Sawah adalah sebesar Rp 191.671.242,-

\section{Dampak ekonomi tidak langsung}

Menurut Septianti (2013) dampak ekonomi tidak langsung dapat dilihat dari pengeluaran pemilik unit usaha di dalam kawasan lokasi wisata. Dalam hal ini 
adalah pembelanjaan yang dikeluarkan oleh pemilik unit usaha di Cafe Sawah merupakan menjadi dampak tidak langsung di lokasi wisata tersebut. Baik pengelola destinasi wisata Cafe Sawah maupun pemilik unit usaha yang melakukan aktivitas usaha di Cafe Sawah telah melakukan perekrutan karyawan atau tenaga kerja yang berasal dari penduduk setempat, sehingga dapat menimbulkan dampak ekonomi secara tidak langsung berupa upah yang diterima oleh tenaga kerja yang bekerja di unit usaha tersebut. Data mengenai pengeluaran unit usaha di dalam dan di luar lokasi wisata dapat dilihat berdasarkan pada Tabel 4 berikut.

Tabel 4. Total Pengeluaran Unit Usaha di Dalam dan di Luar Lokasi Wisata

\begin{tabular}{|c|c|c|c|c|}
\hline \multirow{5}{*}{ Jenis Keterangan } & \multicolumn{4}{|c|}{ Jenis Unit Usaha } \\
\hline & Kios & Kios & Permainan & \\
\hline & Makanan & Oleh-oleh & yang & Usaha \\
\hline & dan & dan & disediakan & Toilet \\
\hline & Minuman & Souvenir & masyarakat & \\
\hline \multicolumn{5}{|l|}{ Pengeluaran dilokasi wisata } \\
\hline Biaya Pembelian Input Bahan Baku & 805.882 & 1.427 .778 & 933.333 & 70.000 \\
\hline Biaya Pemeliharaan & 248.824 & 88.333 & 233.333 & 83.000 \\
\hline Biaya Sewa & 449.000 & 337.889 & 1.666 .667 & 500.000 \\
\hline Jumlah Pengeluaran (Rp/bln) (a) & 1.503 .706 & 1.854 .000 & 2.833 .333 & 653.000 \\
\hline Jumlah Unit Usaha (b) & 48 & 25 & 3 & 1 \\
\hline $\begin{array}{l}\text { Total Pengeluaran di Dalam } \\
\text { Lokasi }(\mathrm{Rp} / \mathrm{bln})\left(\mathrm{c}=\mathrm{a}^{*} \mathrm{~b}\right)\end{array}$ & 72.177.882 & 46.350 .000 & 8.500 .000 & 653.000 \\
\hline \multicolumn{5}{|l|}{ Pengeluaran di luar lokasi wisata } \\
\hline Transport Lokal & 344.706 & 124.444 & 133.333 & 10.000 \\
\hline Retribusi dan Pajak & 147.647 & 7.778 & 23.333 & 40.000 \\
\hline Biaya Operasional (listrik dan air) & 122.235 & 102.111 & 123.333 & 70.000 \\
\hline Jumlah Pengeluaran (Rp/bln) (d) & 614.588 & 234.333 & 280.000 & 120.000 \\
\hline $\begin{array}{l}\text { Total Pengeluaran di luar lokasi } \\
(\mathrm{Rp} / \mathrm{bln})\left(\mathrm{e}=\mathrm{d}^{*} \mathrm{~b}\right)\end{array}$ & 29.500.235 & 5.858 .333 & 840.000 & 360.000 \\
\hline
\end{tabular}

Sumber: Data diolah, 2018

Berdasarkan rata - rata per unit usaha, yang memiliki jumlah pengeluaran tertinggi di dalam lokasi wisata terdapat pada unit usaha kios oleh - oleh dan souvenir dengan rata - rata per unit mengeluarkan biaya sebesar Rp 1.854.000,dengan jumlah pengeluaran terbesar adalah di biaya input pembelian bahan baku rata - rata sebesar Rp 1.427.778,-. Lebih lanjut Septianti (2013) menjelaskan bahwa 
dampak ekonomi tidak langsung juga diperoleh dengan melihat pendapatan tenaga kerja. Dampak tidak langsung yang dirasakan oleh tenaga kerja berupa pendapatan yang diperoleh dapat dilihat pada Tabel 5.

Tabel 5. Dampak Ekonomi Tidak Langsung di Cafe Sawah

\begin{tabular}{|c|c|c|c|c|c|c|c|}
\hline \multirow{3}{*}{ Jenis Unit Usaha } & & & & & \multicolumn{3}{|c|}{ Total } \\
\hline & $\begin{array}{l}\text { Rata } \\
\text {-rata } \\
\text { TK/ } \\
\text { Unit }\end{array}$ & $\begin{array}{l}\Sigma \text { Unit } \\
\text { Usaha } \\
\text { (buah) }\end{array}$ & $\begin{array}{c}\Sigma \\
\text { TK } \\
\text { (org) }\end{array}$ & $\begin{array}{c}\text { Pendapata } \\
\text { n TK } \\
\text { (Rp/bln) }\end{array}$ & $\begin{array}{c}\text { Total } \\
\text { Pendapatan } \\
\text { TK } \\
\text { (Rp/bln) }\end{array}$ & $\begin{array}{c}\text { Pengeluaran } \\
\text { Unit Usaha } \\
\text { di dalam } \\
\text { Lokasi } \\
\text { (Rp/bln) }\end{array}$ & $\begin{array}{c}\text { Total dampak } \\
\text { ekonomi tidak } \\
\text { langsung } \\
\text { (Rp/bln) }\end{array}$ \\
\hline & (a) & (b) & (c) & (d) & $\left(e=c^{*} d\right)$ & (f) & $(g=e+f)$ \\
\hline Kios Makanan & 1 & 48 & 48 & 1.058 .824 & 50.823 .529 & 72.177 .882 & 123.001 .412 \\
\hline Kios Souvenir & 1 & 25 & 25 & 1.171 .429 & 29.285 .714 & 46.350 .000 & 75.635 .714 \\
\hline Permainan & 2 & 3 & 6 & 1.200 .000 & 7.200 .000 & 8.500 .000 & 15.700 .000 \\
\hline \multicolumn{8}{|l|}{ Pengelola } \\
\hline Parkiran & 6 & 1 & 6 & 1.000 .000 & 6.000 .000 & - & 6.000 .000 \\
\hline Toilet & 1 & 4 & 4 & 1.200 .000 & 4.800 .000 & - & 4.800 .000 \\
\hline Kebersihan & 10 & 1 & 10 & 1.000 .000 & 10.000 .000 & - & 10.000 .000 \\
\hline Keamanan & 7 & 1 & 7 & 1.000 .000 & 7.000 .000 & - & 7.000 .000 \\
\hline Gardener & 6 & 1 & 6 & 1.600 .000 & 9.600 .000 & - & 9.600 .000 \\
\hline Ticketing & 6 & 1 & 6 & 1.600 .000 & 9.600 .000 & - & 9.600 .000 \\
\hline Penjaga Masuk & 7 & 1 & 7 & 1.400 .000 & 9.800 .000 & - & 9.800 .000 \\
\hline Outbond & 10 & 1 & 10 & 1.400 .000 & 14.000 .000 & - & 14.000 .000 \\
\hline FO & 7 & 1 & 7 & 1.400 .000 & 9.800 .000 & - & 9.800 .000 \\
\hline Total & 64 & 88 & 142 & 15.030 .252 & 167.909 .244 & 127.027 .882 & 294.937.126 \\
\hline
\end{tabular}

Sumber: Data diolah, 2018

Berdasarkan Tabel 5 proporsi pendapatan tenaga kerja satu dengan yang lain memiliki perbedaan berdasarkan mereka bekerja. Hal ini dikarenakan antara pemilik usaha satu dengan yang lain memiliki hak penuh dalam penentuan pemberian upah tenaga kerja berdasarkan seberapa besar usaha tersebut berjalan. Lebih lanjut, tenaga kerja yang bekerja langsung di Cafe Sawah atau pengelola destinasi memiliki kisaran gaji dari Rp 1.000.000,- sampai dengan Rp 1.200.000,- hal ini dipengaruhi oleh berapa lama mereka bekerja dan pada bagian apa mereka menempati posisi pekerjaan tersebut. Dampak tidak langsung yang dirasakan paling besar dari tenaga kerja adalah tenaga kerja unit usaha makanan dan minuman karena dari sisi jumlah mereka memiliki tenaga kerja terbanyak yaitu sejumlah 48 
tenaga kerja dengan total pendapatan sebesar Rp 50.823.529,- dan ketika dijumlah dengan total pengeluaran unit usaha makanan dan minuman di dalam lokasi wisata sehingga total dampak ekonomi tidak langsung yang dirasakan oleh unit usaha tersebut adalah $\operatorname{Rp} 123.001 .412,-$.

Dampak tidak langsung yang jumlahnya paling kecil berasal dari tenaga kerja pada unit usaha penyedia toilet yaitu sebesar $R p$ 4.800.000,-. Hal tersebut dikarenakan jumlah tenaga kerja pada unit usaha tersebut memiliki jumlah karyawan yang terbatas. Total dampak ekonomi tidak langsung yang dirasakan adalah sebesar Rp 294.937.126,- per bulan.

\section{Dampak ekonomi lanjutan}

Mutiarani (2011) menjelaskan bahwa dampak ekonomi lanjutan merupakan dampak ekonomi yang diperoleh berdasarkan pengeluaran yang dikeluarkan oleh tenaga kerja lokal yang berada di lokasi tersebut. Lebih lanjut dijelaskan bahwa jenis pengeluaran yang dikeluarkan oleh tenaga kerja tersebut antara lain berupa biaya untuk konsumsi keseharian, biaya sekolah anak, biaya listrik, biaya kebutuhan sehari - hari dan biaya transportasi. Secara umum pengeluaran tenaga kerja tersebut dibagi menjadi dua yaitu pengeluaran di dalam lokasi wisata serta pengeluaran di luar lokasi wisata. Adapun proporsi pengeluaran tenaga kerja tersebut dapat dilihat pada Tabel 6. 
Dampak Ekonomi Pengembangan Community Based Tourism...

Tabel 6. Proporsi Pengeluaran Tenaga Kerja Cafe Sawah

\begin{tabular}{|c|c|c|c|c|c|c|c|c|}
\hline \multirow{3}{*}{$\begin{array}{c}\text { Tenaga Kerja } \\
\text { (TK) }\end{array}$} & \multicolumn{5}{|c|}{ Proporsi Pengeluaran di Sekitar DTW } & \multicolumn{3}{|c|}{$\begin{array}{c}\text { Proporsi Pengeluaran di } \\
\text { Luar DTW }\end{array}$} \\
\hline & $\begin{array}{c}\text { Biaya } \\
\text { Konsumsi } \\
(\%)\end{array}$ & $\begin{array}{c}\text { Biaya } \\
\text { Kebutuhan } \\
\text { harian (\%) }\end{array}$ & $\begin{array}{c}\text { Biaya } \\
\text { Trans- } \\
\text { portasi } \\
(\%)\end{array}$ & $\begin{array}{c}\text { Biaya } \\
\text { Anak } \\
\text { Sekolah } \\
(\%)\end{array}$ & $\begin{array}{c}\text { Total } \\
(\%)\end{array}$ & $\begin{array}{c}\text { Biaya } \\
\text { Listrik } \\
(\%)\end{array}$ & $\begin{array}{c}\text { Biaya } \\
\text { Lainnya } \\
(\%)\end{array}$ & $\begin{array}{c}\text { Total } \\
(\%)\end{array}$ \\
\hline & (a) & (b) & (c) & (d) & $\begin{array}{c}(\mathrm{e}=\mathrm{a}+\mathrm{b}+ \\
\mathrm{c}+\mathrm{d})\end{array}$ & (f) & (g) & $(\mathrm{h}=\mathrm{f}+\mathrm{g})$ \\
\hline Kios Makanan & 41,96 & 24,47 & 10,84 & 11,78 & 89,05 & 5,21 & 5,74 & 10,95 \\
\hline Kios Souvenir & 52,7 & 23,43 & 11,57 & 6,59 & 94,29 & 2,78 & 2,93 & 5,71 \\
\hline Permainan & 35,00 & 47,50 & 0,00 & 0,00 & 82,50 & 6,50 & 11,00 & 17,50 \\
\hline \multicolumn{9}{|l|}{ Pengelola } \\
\hline Parkiran & 43,48 & 21,74 & 32,61 & 0,00 & 97,83 & 2,17 & 0,00 & 2,17 \\
\hline Toilet & 45,45 & 0,00 & 18,18 & 0,00 & 63,64 & 0,00 & 36,36 & 36,36 \\
\hline Kebersihan & 52,63 & 5,26 & 0,00 & 0,00 & 57,89 & 0,00 & 42,11 & 42,11 \\
\hline Keamanan & 26,91 & 1,35 & 26,91 & 0,00 & 55,16 & 17,94 & 26,91 & 44,84 \\
\hline Gardener & 20,69 & 51,72 & 20,69 & 0,00 & 93,10 & 0,00 & 6,90 & 6,90 \\
\hline Ticketing & 19,33 & 32,22 & 1,93 & 0,00 & 53,48 & 1,42 & 45,10 & 46,52 \\
\hline Penjaga Masuk & 44,44 & 14,81 & 22,22 & 0,00 & 81,48 & 0,00 & 18,52 & 18,52 \\
\hline Outbond & 58,82 & 0,00 & 35,29 & 0,00 & 94,12 & 3,53 & 2,35 & 5,88 \\
\hline FO & 48,82 & 15,00 & 30,29 & 0,00 & 94,12 & 2,50 & 3,38 & 5,88 \\
\hline Rata-rata & 41,69 & 18,54 & 17,96 & 1,53 & 79,72 & 3,59 & 16,69 & 20,28 \\
\hline
\end{tabular}

Sumber: Data diolah, 2018

Berdasarkan Tabel 6 dapat proporsi pengeluaran tenaga kerja di dalam lokasi wisata Cafe Sawah adalah sebesar 79,72 persen. Angka tersebut merupakan pengeluaran tenaga kerja di dalam lokasi wisata yang menjadi dampak ekonomi lanjutan dari kegiatan wisata di Cafe Sawah Pujon Kidul. Berdasarkan beberapa proporsi pengeluaran, biaya konsumsi menjadi angka proporsi pengeluaran paling besar dibandingkan dengan proporsi ke lima biaya lainnya, baik kebutuhan harian, biaya transportasi, biaya anak sekolah, biaya listrik, maupun biaya lain - lain. Berdasarkan proporsi pengeluaran tenaga kerja, diperoleh biaya konsumsi rata rata sebesar 41,69 persen. Nilai tertinggi proporsi pengeluaran biaya konsumsi adalah berada pada karyawan Outbond yaitu sebesar 58,82 persen sedangkan terendah terjadi pada karyawan ticketing yaitu sebesar 19,33 persen. Hal tersebut 
dipengaruhi oleh karakteristik tenaga kerja yang bekerja disetiap bagian tersebut. Dampak lanjutan dari keberadaan destinasi wisata Cafe Sawah dapat dilihat dari jumlah pengeluaran tenaga kerja yang dilakukan di dalam lokasi wisata. Data mengenai dampak lanjutan yang terjadi pada Cafe Sawah dapat dilihat pada Tabel 7.

Tabel 7. Dampak Ekonomi Lanjutan di Destinasi Cafe Sawah

\begin{tabular}{|c|c|c|c|c|}
\hline Tenaga Kerja & $\begin{array}{c}\text { Jumlah TK } \\
\text { keseluruhan } \\
\text { (org) }\end{array}$ & $\begin{array}{c}\text { Total } \\
\text { Pengeluaran } \\
\text { TK/Bulan } \\
\text { (Rp/bln) }\end{array}$ & $\begin{array}{c}\text { Proporsi } \\
\text { Pengeluaran } \\
\text { TK di DTW } \\
(\%)\end{array}$ & $\begin{array}{l}\text { Dampak } \\
\text { Ekonomi } \\
\text { Lanjutan } \\
\text { (Rp/bln) }\end{array}$ \\
\hline & (a) & (b) & (c) & $\left(d=a^{*} b^{*} c\right)$ \\
\hline Kios Makanan & 48 & 1.306 .154 & 89,05 & 55.827 .692 \\
\hline Kios Souvenir & 25 & 975.714 & 94,29 & 23.000 .000 \\
\hline Permainan & 6 & 1.000 .000 & 82,50 & 4.950 .000 \\
\hline \multicolumn{5}{|l|}{ Pengelola } \\
\hline Parkiran & 6 & 920.000 & 97,83 & 5.400 .000 \\
\hline Toilet & 4 & 1.100 .000 & 63,64 & 2.800 .000 \\
\hline Kebersihan & 10 & 950.000 & 57,89 & 5.500 .000 \\
\hline Keamanan & 7 & 1.115 .000 & 55,16 & 4.305 .000 \\
\hline Gardener & 6 & 1.450 .000 & 93,10 & 8.100 .000 \\
\hline Ticketing & 6 & 1.552 .000 & 53,48 & 4.980 .000 \\
\hline $\begin{array}{l}\text { Penjaga } \\
\text { Masuk }\end{array}$ & 7 & 1.350 .000 & 81,48 & 7.700 .000 \\
\hline Outbond & 10 & 850.000 & 94,12 & 8.000 .000 \\
\hline FO & 7 & 850.000 & 94,12 & 5.600 .000 \\
\hline Total & 142 & 13.418 .868 & 79,72 & 136.162 .692 \\
\hline
\end{tabular}

Sumber: Data diolah, 2018

Berdasarkan pada Tabel 7 dapat dilihat bahwa rata - rata dampak ekonomi lanjutan secara keseluruhan dari keberadaan Cafe Sawah adalah sebesar Rp 136.162.692,- per bulan, dengan pengeluaran tenaga kerja tertinggi berada pada kios makanan yaitu sebesar Rp 55.827.692,- per bulan. Hal tersebut dikarenakan jumlah tenaga kerja pada kios makanan memiliki jumlah tertinggi dibandingkan jumlah tenaga kerja lainnya yaitu sebanyak 48 orang tenaga kerja. Dampak lanjutan tersebut merupakan dampak yang dikeluarkan oleh tenaga kerja yang memiliki pendapatan 
dari aktivitas wisata Cafe Sawah dengan membelanjakannya di area lokasi tersebut seperti contohnya kebutuhan pangan, biaya kebutuhan sehari - hari, biaya sekolah anak apabila sudah berkeluarga, serta biaya transportasi lokal yang dikeluarkan oleh tenaga kerja selama satu bulan.

\section{Multiplier effect Destinasi Wisata Cafe Sawah}

Nilai dari efek penggandaan / multiplier effect merupakan sebuah alat ukur untuk melihat seberapa besar kegiatan pariwisata di lokasi tersebut memberikan dampak ekonomi terhadap masyarakat khususnya dalam hal pendapatan. Berdasarkan sebuah lembaga Marine Ecotourism for Atlantic Area (META) dalam Anonim (2001) dampak ekonomi terhadap masyarakat lokal dapat diukur menggunakan dua tipe penggandaan yaitu (1) Keynesian Multiplier Effect, yaitu nilai yang menunjukkan berapa besar pengeluaran pengunjung berpengaruh terhadap peningkatan pendapatan masyarakat lokal, (2) Ratio Income Multiplier, yaitu nilai yang menunjukkan seberapa besar dampak langsung yang dirasakan dari pengeluaran pengunjung berdampak terhadap perekonomian lokal. Dalam hal penggandaan ini mengukur dua dampak yaitu dampak tidak langsung dan dampak lanjutan yang terjadi. Data mengenai nilai efek penggandaan dari pengeluaran wisatawan di masing - masing destinasi baik Cafe Sawah dan Pasar Parkiran dapat dilihat pada Tabel 8.

Tabel 8. Komparasi Multiplier Effect Cafe Sawah

\begin{tabular}{lc}
\hline \multicolumn{1}{c}{ Multiplier } & Nilai Cafe Sawah \\
\hline Keynesian Income Multiplier & 0,27 \\
Ratio Income Multiplier Tipe I & 2,54 \\
Ratio Income Multiplier Tipe II & 3,25 \\
\hline
\end{tabular}

Sumber: Data diolah (Lampiran 01), 2018

Berdasarkan dampak ekonomi langsung, tidak langsung, dan dampak lanjutan destinasi wisata Cafe Sawah yang telah dibahas maka dapat diperoleh multiplier effect dari destinasi tersebut seperti pada Tabel 8. Berdasarkan Tabel 8 
dapat dilihat bahwa Keynesian Income Multiplier pada destinasi wisata Cafe Sawah sebesar 0,27 artinya setiap peningkatan Rp 1.000,00 pengeluaran wisatawan akan memiliki dampak terhadap ekonomi lokal sebesar Rp270,00. Nilai Ratio Income Multiplier tipe I sebesar 2,54 artinya setiap peningkatan Rp 1.000,00 pada penerimaan unit usaha mengakibatkan peningkatan sebesar Rp2.540,00 terhadap pendapatan pemilik usaha dan tenaga kerja. Lebih lanjut, nilai Ratio Income Multiplier tipe II sebesar 3,25 menunjukkan bahwa setiap kenaikan Rp 1.000,00 pada penerimaan unit usaha akan meningkatkan Rp 3.250,00 pada pendapatan pemilik usaha, pendapatan tenaga kerja, dan pengeluaran konsumsi tenaga kerja di ekonomi tingkat lokal yang akan berputar pada masyarakat lokal. Untuk mengetahui lebih lanjut mengenai rincian penghitungan multiplier effect yang terjadi pada setiap destinasi wisata dapat dilihat pada lampiran 01.

Menurut META dalam Anonim (2001) Apabila nilai multiplier effect diantara angka nol dan satu $(0<x<1)$, maka destinasi tersebut di dalam aktivitas wisatanya masih memiliki nilai dampak ekonomi yang rendah khususnya terhadap pendapatan masyarakat, sehingga dapat disimpulkan bahwa secara umum pengeluaran wisatawan selama di destinasi wisata Cafe Sawah masih memberikan dampak pendapatan yang masih kecil dilihat dari nilai keynesian multiplier sebesar 0,27 atau masuk dalam kategori $(0<\mathrm{X}<1)$. Nilai Ratio Income Multiplier di destinasi Cafe Sawah telah memberikan dampak yang besar terhadap masyarakat sekitar yang melakukan aktivitas di destinasi wisata dilihat dari nilai tersebut sudah lebih besar daripada $1(>1)$.

Dampak yang terjadi saat ini adalah masyarakat belum siap dan mampu untuk menerima dan bekerja secara profesional dalam hal pelayanan sehingga pendapatan yang diterima saat ini masih sedkit. Berbeda dengan Pasar Parkiran yang memang dikelola oleh sebuah perusahaan di mana profesionalitas karyawan sangat dituntut. Dengan adanya profesionalistas yang dimiliki oleh karyawan atau tenaga kerja baik tenaga kerja yang ada di destinasi wisata maupun tenaga kerja yang berada di stand - stand yang menjual makanan dan minuman maka gaji yang 278 JUMPA Volume 05, Nomor 02, Januari 2019 
diterima berbeda. Rata - rata gaji yang diterima oleh tenaga kerja yang ada di Pasar Parkiran adalah lebih dari Rp 2.000.000,- sedangkan tenaga kerja yang ada di Cafe Sawah memiliki upah kerja rata - rata Rp 1.300.000,-

Seperti halnya yang terjadi pada pengelolaan pendapatan di destinasi Cafe Sawah yaitu penerimaan yang didapat dari penjualan makanan dan minuman menjadi penerimaan kas keuangan desa dan masuk BUMDes. Untuk merasakan dampak aktivitas pariwisata di destinasi tersebut masyarakat diberikan ruang usaha berupa kios - kios untuk berjualan di sekitar destinasi. Permasalahan yang terjadi adalah masyarakat yang melakukan aktivitas usaha di Cafe Sawah memiliki kesamaan dengan usaha yang ditawarkan oleh pengelola Cafe Sawah yaitu kuliner. Sehingga unit usaha harus bersaing dengan pengelola Cafe Sawah yaitu sebagian besar unit usaha melakukan usaha kuliner.

Dampak dari persaingan itu adalah terkadang unit usaha menjadi sepi di hari biasa dan bukan libur akhir pekan karena wisatawan lebih memilih makanan yang ditawarkan oleh Cafe Sawah daripada kuliner yang ditawarkan oleh unit usaha. Hal ini terbukti ketika dilakukan wawancara terhadap beberapa Responden Pemilik Unit Usaha, terdapat unit usaha yang mengeluhkan usahanya kurang begitu laku di hari - hari biasa karena sepinya pembeli. Ketika musim liburan dan akhir pekan datang, barulah pedagang / unit usaha tersebut mendapatkan pembeli yang mungkin tidak berkenan untuk menikmati makanan yang ditawarkan oleh Cafe Sawah tersebut.

Hal ini tidak sesuai dengan penelitian yang dilakukan oleh nurhidayati (2015) yang berpendapat bahwa CBT merupakan sebuah alternatif pengembangan pariwisata yang dianggap lebih menguntungkan masyarakat setempat dan menjamin keberlanjutan pariwisata. Seperti yang telah diungkapkan pada pembahasan sebelumnya CBT memang merupakan model pengelolaan yang bagus dan lebih berpihak terhadap masyarakat asalkan ada pengelolaan yang benar dan transparansi sharing profit terhadap masyarakat. Selain transparansi, kebebasan partisipasi masyarakat juga seharusnya terjadi dalam pengelolaan sebuah destinasi 
yang menggunakan model CBT. Hal ini belum terjadi pada pengelolaan wisata Cafe Sawah di mana pengelolaan di serahkan kepada Pokdarwis dan masyarakat hanya diberi ruang usaha pendirian kios di sekitar destinasi wisata apabila ingin mendapatkan pembagian kue pariwisata. Kepada masyarakat yang tidak melakukan usaha dan tidak ada aktivitas di destinasi tersebut, tidak mendapatkan dampak apapun meskipun masyarakat tersebut merupakan penduduk lokal Pujon Kidul.

\section{Simpulan dan Saran}

Simpulan yang dapat diambil dalam dari penelitian ini adalah berdasarkan pengeluaran wisatawan yang dilakukan di dalam lokasi wisata Cafe Sawah selama satu tahun dapat dilihat rata - rata per bulan sebesar Rp 2.342.087.302,- dengan proporsi pengeluaran wisatawan di dalam lokasi adalah sebesar 57,07 persen. Lebih lanjut berdasarkan pengeluaran tersebut telah memberikan damapk terhadap masyarakat sekitar lokasi berupa dampak ekonomi langsung (D) yaitu sebesar Rp191.671.242,-; dampak ekonomi tidak langsung (N) sebesar Rp294.937.126,-; serta dampak ekonomi lanjutan (U) sebesar Rp136.162.692,--. Lebih lanjut, setelah dianalisis menggunakan teori dampak penggandaan Keynesian Income Multiplier dan Ratio Income Multiplier didapatkan angka sebesar 0,27 untuk Keynesian Income Multiplier dan 2,54 untuk Ratio Income Multiplier Tipe I serta 3,25 untuk nilai Ratio Income Multiplier Tipe II. Karena angka Keynesian Income Multiplier belum memenuhi angka 1 sehingga dapat ditarik kesimpulan bahwa aktivitas pariwisata berupa pengeluaran wisatawan belum dapat memberikan dampak ekonomi yang signifikan terhadap perputaran uang dan perekonomian masyarakat setempat.

Saran yang dapat diberikan dalam penelitian ini adalah perlu adanya perhatian khusus oleh lembaga terkait mengenai perputaran uang dan kebocoran kebocoran yang tejadi sehingga masyarakat akan dapat merasakan dampak dari aktivitas pariwisata di lokasi tersebut khususnya Cafe Sawah. 


\section{Daftar Pustaka}

Anonim, 2001. Planning for Marine Ecotourism in the EU Atlantic Area, Good Practice Guide. Marine Ecotourism for Atlantic Area (META). Bristol: University of The West of England.

Badan Pusat Statistik. 2014. Statistik Indonesia. Jakarta: BPS

Cohen, E. 1984. 'The Sosiology of Tourism : Approach, Issues and Finding', Annal of Tourism Reseach, Vol. 10, pp. 373-392.

Dritasto, A dan Annisa AA. 2013. 'Analisis Dampak Ekonomi Wisata Bahari Terhadap Pendapatan Masyarakat Di Pulau Tidung', Reka Loka-Jurnal Online Institut Teknologi Nasional, Vol. 10(20), pp. 1-8.

Haryanto, J T. 2014. Model Pengembangan Ekowisata Dalam Mendukung Kemandirian Ekonomi Daerah Studi Kasus Provinsi DIY. Kementerian Keuangan.

Kementerian Pariwisata, 2016. "Laporan Akuntabilitas Kinerja Kementerian Pariwisata Tahun 2015". Jakarta: Biro Perencanaan Dan Keuangan Sekretariat Kementerian Pariwisata.

McIntyre, G. 1993. Sustainable Tourism Development: Guide for Local Planner. Madrid: World Tourism Organization

Muljadi, A J. 2012. Kepariwisataan dan Perjalanan. Jakarta: Rajagrafindo Persada.

Mutiarani, N. 2011. “Analisis Dampak Ekonomi dan Nilai Ekonomi Manfaat Rekreasi Situ Cipondoh Tangerang". Skripsi. Bogor: Institut Pertanian Bogor.

Nurhidayati, S E. 2015. "Studi evaluasi Community Based Tourism (CBT) sebagai pendukung agrowisata berkelanjutan", Jurnal Masyarakat, Kebudayaan dan Politik, Vol. 28, No. 1 pp. 1-11

Septianti, N W. 2013. “Estimasi Dampak Ekonomi Kawasan Taman Wisata Matahari Cilember, Kabupaten Bogor Terhadap Masyarakat Sekitar". Skripsi. Bogor: Institut Pertanian Bogor

Sunaryo, B. 2013. Kebijakan Pembangunan Destinasi Pariwisata, Konsep dan Aplikasinya di Indonesia. Yogyakarta: Gava Media.

Tantina, W I. 2018. “Manajemen Strategi Pengembangan Objek Pariwisata Cafe Sawah (Studi Pada Dinas Pariwisata dan Kebudayaan Kabupaten Malang)", Publika Jurnal Ilmu Administrasi Negara, Vol. 6(1), pp. 1-10

Yoeti, O A. 2008. Ekonomi Pariwisata: Introduksi, Informasi dan Implementasi. Jakarta: Penerbit Kompas. 


\section{Profil Penulis}

Tomi Agfianto, A.Md., S.ST.Par., M.Par adalah alumnus Magister Pariwisata Universitas Udayana, Denpasar - Bali pada tahun 2018. Dia menyelesaikan Program D3 Usaha Perjalanan Wisata di Universitas Brawijaya Malang dan D4 Administrasi Hotel Sekolah Tinggi Pariwisata AMPTA, Yogyakarta di tahun 2014. Dalam menyelesaikan Studi Magisternya dia mendapatkan kesempatan mengikuti Program Joint Curriculum selama satu semester yang diselenggarakan oleh Program Studi Master of Tourism Development Strategy Hochschule Stralsund, Germany. Minat penelitian penulis yang juga merupakan dosen Sarjana Terapan Manajemen Perhotelan Universitas Brawijaya Malang ini adalah di bidang Pariwisata dan Perhotelan secara umum dan ekonomi terkait secara khusus. Email: tomi.agfiant@gmail.com;

Prof. Dr. Ir. Made Antara, MS merupakan Guru Besar Fakultas Pertanian Universitas Udayana. Saat ini dia merupakan salah satu Dosen PS. Agribisnis Fakultas Pertanian. Selain mengajar pada Fakultas Pertanian, dia merupakan dosen pada beberapa Program Studi lain di lingkungan Universitas Udayana diantaranya adalah Program Magister Pariwisata dan Program Doktor Pariwisata pada Fakultas Pariwisata serta Program Doktor Kajian Budaya Universitas Udayana. Email: antara_unud@yahoo.com;

Dr. I Wayan Suardana, S.ST.Par., M.Par Merupakan Wakil Dekan I Fakultas Pariwisata Universitas Udayana Periode 2018 - 2021 selain menjabat sebagai Wakil Dekan II dia juga merupakan Dosen Prodi S1 Industri Perjalanan Wisata dan S2 Pariwisata Fakultas Pariwisata. Menamatkan Diploma IV Pariwisata di Universitas Udayana pada tahun 2001. Sebelumnya memperoleh gelar magister pada Program Magister Kajian Pariwisata Konsentrasi Perencanaan Pariwisata Universitas Udayana pada tahun 2004. Pada tahun 2015 meraih gelar doktor pariwisata dari Universitas Udayana. Saat ini tercatat sebagai dosen PNS pada Universitas Udayana. Email: suar.dana@gmail.com. 